\title{
Cadmium Resistance, Microbial Biosorptive Performance and Mechanisms of a Novel Biocontrol Bacterium Paenibacillus sp. LYX-1
}

\section{Yixin Luo}

Zhejiang University

Min Liao ( $D$ liaomin@zju.edu.cn )

Zhejiang University https://orcid.org/0000-0001-9078-204X

\section{Yuhao Zhang}

Zhejiang University

$\mathrm{Na} \mathrm{Xu}$

Zhejiang University

Xiaomei Xie

Zhejiang University

\section{Qiyan Fan}

Zhejiang University

\section{Research Article}

Keywords: Paenibacillus sp., Cd resistance, Biosorption, Mechanism

Posted Date: November 16th, 2021

DOI: https://doi.org/10.21203/rs.3.rs-1003036/v1

License: (c) (i) This work is licensed under a Creative Commons Attribution 4.0 International License.

Read Full License 
3 The Full Title: Cadmium resistance, microbial biosorptive performance and

$4 \quad$ mechanisms of a novel biocontrol bacterium Paenibacillus sp. LYX-1

5 Name of authors : YiXin Luo ${ }^{a, b}$, Min Liao ${ }^{a, b *}$, Yuhao Zhang ${ }^{\text {a,b }}, \mathrm{Na} \mathrm{Xu}^{\mathrm{a}, \mathrm{b}}$, Xiaomei $6 \mathrm{Xie}^{\mathrm{a}, \mathrm{c}^{*}}$, Qiyan Fan ${ }^{\mathrm{a}, \mathrm{c}}$

7 a. College of Environmental and Resource Science, Zhejiang University, Yuhangtang 8 Road No.866, Hangzhou 310058 China

9 b. Zhejiang Provincial Key Laboratory of Agricultural Resources and Environment, 10 Yuhangtang Road No.866, Hangzhou 310058, China

11 c. National Demonstration Center for Experimental Environmental and Resources 12 Education (Zhejiang University), Yuhangtang Road No.866, Hangzhou 310058, China 13 First author: YiXin Luo.

14 *Corresponding author: Min Liao; Xiaomei Xie

E-mail: 1iaomin@zju.edu.cn; xiexiaomei@zju.edu.cn

Telephone: $+86-15372058710$

Fax: $+86-571-8892719$

Financial support: This work was supported by the National Key Research and 


\title{
Cadmium resistance, microbial biosorptive performance
} and mechanisms of a novel biocontrol bacterium

\section{Paenibacillus sp. LYX-1}

\author{
Yixin Luo a,b, Min Liao a,b*, Yuhao Zhang ${ }^{\mathrm{a}, \mathrm{b}}, \mathrm{Na} \mathrm{Xu}^{\mathrm{a}}{ }^{\mathrm{a} b}$, Xiaomei Xie a,c*, Qiyan Fan ${ }^{\mathrm{a}, \mathrm{c}}$ \\ a. College of Environmental and Resource Science, Zhejiang University, Yuhangtang Road No.866, \\ Hangzhou 310058 China
}

b. Zhejiang Provincial Key Laboratory of Agricultural Resources and Environment, Yuhangtang Road No.866, Hangzhou 310058, China

c. National Demonstration Center for Experimental Environmental and Resources Education (Zhejiang University), Yuhangtang Road No.866, Hangzhou 310058, China

\section{*Corresponding author,E-mail: liaomin@zju.edu.cn; xiexiaomei@zju.edu.cn}

Abstract: In order to explore whether the newly discovered biocontrol strain Paenibacillus sp., LYX-1 having antagonistic effect on peach brown rot was resistant to $\mathrm{Cd}^{2+}$, a series of growth of strain LYX-1 under different Cd concentration and biosorption experiments were conducted to living and dead strain LYX-1. Meanwhile, the $\mathrm{Cd}^{2+}$ resistance and biosorption mechanisms were further identified by Cd-resistant genes, TEM, SEM-EDS, FTIR and XPS analysis. The results showed that strain LYX-1 could resist $50 \mathrm{mg} / \mathrm{L} \mathrm{Cd}^{2+}$ and the adsorption process of both living and dead strain LYX-1 all satisfied the pseudo-second kinetic equation. Under $\mathrm{pH} 8.0$ and at a dose of $1.0 \mathrm{~g} / \mathrm{L}$ strain, the removal capacities of living and dead cells were as high as $90.39 \%$ and $75.67 \%$ at $20 \mathrm{mg} / \mathrm{L} \mathrm{Cd}^{2+}$, respectively. For the adsorption isotherm test, results revealed that both Langmuir $\left(\mathrm{R}^{2}=0.9704\right)$ and Freundlich $\left(\mathrm{R}^{2}=0.9915\right)$ model could describe the $\mathrm{Cd}^{2+}$ biosorption well for living strain LYX-1. The maximum equilibrium biosorption capacities of living and dead biomass were 30.6790 and $24.3752 \mathrm{mg} / \mathrm{g}$, respectively. The adsorption mechanism was controlled by chemisorption with $-\mathrm{OH},-\mathrm{NH},-\mathrm{C}=\mathrm{O}, \mathrm{O}=\mathrm{C}-\mathrm{O}, \mathrm{C}-\mathrm{N}, \mathrm{S}^{2-}$ and phosphate functional groups on the cell surface of strain LYX-1, which were further identified by XPS. The insignificant biosorption difference of living and dead biomass was caused by CzcD gene in strain LYX-1 detoxifying 
cadmium through the heavy metal efflux system. The above results indicated that strain LYX-1 had higher tolerance and fixed capacity to $\mathrm{Cd}^{2+}$.

Keywords: Paenibacillus sp.; Cd resistance; Biosorption; Mechanism

\section{Introduction}

Heavy metals (HMs) are the main pollutants in the development of mineral resources, textile, fertilizer manufacturing, metal smelting and processing(Jin et al. 2019). Cadmium (Cd) designated as one of the priority pollutants controlled by many countries can participate in food chain cycle, accumulate in the organism and eventually cause irreversible tubular damage in kidney after it enters the environment(Jin et al. 2020). Therefore, effective treatment of heavy metal Cd pollution in soil and water has become an important issue that needs to be solved urgently in the field of environmental protection today.

Compared with conventional chemical precipitation, electrolysis, reverse osmosis, ion exchange, etc., microbial adsorption had significant advantages, mainly including high efficiency, abundant raw materials, coupled with high chemical activity(Li et al. 2018, Shi et al. 2021, Sun et al. 2020). Additionally, in domestic and international literatures, more and more strains employed as environmentally friendly biomasses have been applied in the removal of metal ions, such as Comamonas sp. XL8(Shi et al. 2021), Enterbacter sp. DNB-S2(Sun et al. 2020), Serratia liquefaciens CL-1 and Bacillus thuringiensis X3(Han et al. 2018). Besides, numerous evidences have proved that biological cell components (e.g., cell wall polysaccharides, proteins, carboxyl in lipid molecules, hydroxyl, carbonyl, phosphoryl, sulfhydryl) realized the accumulation and purification of heavy metals through chelation, ion exchange, biosorption, inorganic micro-precipitation, redox and diffusion(Huang et al. 2014, Özdemir et al. 2009, Tan et al. 2020, Zhou et al. 2018).

At present, the environment polluted by HMs is widespread, and there are few reports on the adaptability of the currently used biocontrol bacterium as microbial materials for heavy metal pollution control under the stress of HMs. The search and discovery of biocontrol bacterium that have high tolerance and immobilization to HMs 
is great significance to the restoration and utilization of heavy metal contaminated soils. Paenibacillus sp. is a kind of significant disease biological control microorganism, which due to their ability to produce-variety of enzymes of degrading the cell wall, e.g. chitinases, cellulases, proteases and $\beta$-1,3-glucanases(Hao et al. 2017). In the previous study, Paenibacillus sp. showed diverse antagonistic activities against five phytopathogenic fungi (Fusarium graminearum, Magnaporthe oryzae, Rhizoctonia solani, Sclerotinia sclerotiorum, and Botrytis cinerea)(Ali et al. 2020). Researches over the past decades showed that Paenibacillus sp. could produce a variety of antibiotics, polymyxin, hydrolases and other antagonistic substances(Ali et al. 2020, Araujo et al. 2020), which was one of the important mechanisms for the biocontrol of Paenibacillus sp.(Hao et al. 2017). Paenibacillus sp. can not only offer protection against bacteria, fungi, nematodes and viruses, but also has advantages of non-pathogenicity, nontoxicity, good environmental compatibility, less residue, safety for humans and animals. Nevertheless, the survival of biocontrol bacterium employed for prevention and control of plant diseases are prone to be threatened by toxic $\mathrm{Cd}$, pests and diseases in composite pollutant sites(Olaniran et al. 2013). Therefore, finding a Paenibacillus sp. with high tolerance and fixation capacity for $\mathrm{Cd}$ is of great significance for the simultaneous control of soil Cd pollution and plant rhizosphere disease. However, relevant studies are rarely reported.

In present work, a novel biocontrol strain Paenibacillus sp. LYX-1 having antagonistic to peach brown rot and higher $\mathrm{Cd}$ resistance was isolated from soil in peach orchard. The $\mathrm{Cd}$ resistance, microbial biosorptive performance and mechanisms of Paenibacillus sp. LYX-1 were studied, including (1) investigate the Cd resistance of biocontrol Paenibacillus sp. LYX-1, (2) compare the biosorption process of living and dead biosorbents, closer to the real-world scenarios where nutrients are deficient, (3) describe the biosorption performance of living and dead cells via kinetic and isotherm models and (4) explore the $\mathrm{Cd}^{2+}$ resistance and removal mechanisms through HMs gene coding, TEM, SEM-EDS, FTIR and XPS analysis. The objective of such work is to provide a theoretical basis focusing a Paenibacillus sp. LYX-1 with higher Cd resistance to realize the simultaneous control of soil $\mathrm{Cd}$ pollution and plant 
rhizosphere disease in Cd stress soil in future.

\section{Materials and methods}

\subsection{Isolation and identification of biocontrol strain}

Biocontrol strain was isolated as following steps. Ten $\mathrm{g}$ of rhizosphere soil in peach orchard in Fenghua city, Zhejiang province, China was initially suspended in $90 \mathrm{~mL}$ of sterile water and incubated at $180 \mathrm{rpm}, 30^{\circ} \mathrm{C}$ for $1 \mathrm{~h}$. The gradient dilution method was used to dilute the soil into soil suspensions with sterile water. $0.1 \mathrm{~mL} 10^{-4}, 10^{-5}$ and $10^{-6}$ gradient dilutions were applied to Luria-Bertani's (LB) agar plate consisted of $10 \mathrm{~g} / \mathrm{L}$ tryptone, $5.0 \mathrm{~g} / \mathrm{L}$ yeast extract, $10.0 \mathrm{~g} / \mathrm{L} \mathrm{NaCl}$ and $20.0 \mathrm{~g} / \mathrm{L}$ agar. There replicates for each gradient were incubated at $30^{\circ} \mathrm{C}$. (1) Primer screening: $6 \mathrm{~mm}$ diameter peach brown rot fungus taken by a hole puncher was placed in the center of the PDA plate. And then, the strains to be screened were placed on 4 corners $3 \mathrm{~cm}$ away from the center of the plate and incubated at $28^{\circ} \mathrm{C}$ for $48 \mathrm{~h} .24$ strains that shrunk the hyphae of the pathogenic bacteria were selected and saved as the re-screening objects. (2) Fine screening: Using the plate confrontation method, the pathogenic bacteria was inoculated in the center of PDA plate, and the re-screening strains were spotted in 3 positions $2.5 \mathrm{~cm}$ away the pathogenic bacteria cake with a sterile inoculation loop to inoculate only the peach brown rot fungus. Three replicates plates was incubated at $28^{\circ} \mathrm{C}$ for 7 days to observe the antibacterial effect. And representative single colony that had highest antagonistic was selected and kept at $4^{\circ} \mathrm{C}$ to be tested.

The 16S rDNA extracted from the strain with highest antagonistic effect on peach brown rot, as a PCR template, was amplified and sequenced using the universal primers 27F (5' -AGTTTGATCMTGGCTCAG-3' ) and 1492R (5' -GGTTACCTTGTTACGACTT-3' ) according to previous study(Galkiewicz and Kellogg 2008). Nucleotide sequence was compared in GenBank database (Nucleotide Blast) using the BLAST search tool to accurately identify the bacterium(Tan et al. 2020). Meanwhile the Neighbor-joining method was selected to construct sequencing results of biocontrol strain into a Phylogenetic tree through MEGA 7.0 software.

\subsection{Cell growth curves under Cd stress}


The pure cultured strain LYX-1 at logarithmic growth phase $\left(\mathrm{OD}_{600}=1.5 \pm 0.2\right)$

were seeded in $\mathrm{LB}$ medium containing different $\mathrm{Cd}^{2+}$ concentrations $(0,5,10,20,50$, $100 \mathrm{mg} / \mathrm{L}$ ) at $2 \%$ inoculation amount, meanwhile, conical flasks were incubated at $30^{\circ} \mathrm{C}$ with $150 \mathrm{rpm}$ on a shaker. The $\mathrm{OD}_{600}$ values were monitored at different time intervals using ultraviolet spectrophotometer (Shimadzu UV-2450, Japan) to construct growth curves. The $\mathrm{Cd}$ ion stock solution used in the above experiment was prepared in 1000 $\mathrm{mL}$ volumetric flask by dissolving $2.74 \mathrm{~g} \mathrm{Cd}\left(\mathrm{NO}_{3}\right)_{2} \cdot 4 \mathrm{H}_{2} \mathrm{O}$ (analytical grade) purchased from Sinopharm Chemical Reagent Co., Ltd (Shanghai, PRC) in deionized water

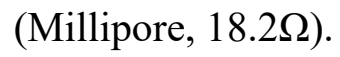

\subsection{Sorbents preparation}

The pure cultured strain LYX-1 was seeded in $600 \mathrm{~mL}$ sterile LB medium in 1000 $\mathrm{mL}$ flasks at $1 \%$ inoculation amount and cultured for $48 \mathrm{~h}$ at $30^{\circ} \mathrm{C}, 150 \mathrm{rpm}$ on a constant temperature shaker. Living cell adsorbent was prepared by centrifuging the bacterium suspension at $4^{\circ} \mathrm{C}, 8000 \mathrm{rpm}$ for $10 \mathrm{~min}$, while dead cell adsorbent was harvested by centrifuging the bacterial suspension that has been sterilized at $121^{\circ} \mathrm{C}$ for 30 min. Both living and dead pellet were washed 3 times and re-suspended with sterile water, then biomass was stored in a $4^{\circ} \mathrm{C}$ refrigerator until use. The concentration (grams per liter) of above cell suspension was tested by drying an aliquot to constant weight at $80^{\circ} \mathrm{C}$ (Huang et al. 2013, Xu et al. 2020).

\subsection{Biosorption C $\mathrm{d}^{2+}$ experiments by strain LYX-1}

\subsection{1 pH effects}

The initial solution $\mathrm{pH}$ values for sorption experiment were adjusted using $1 \mathrm{M}$ $\mathrm{NaOH}$ and $1 \mathrm{M} \mathrm{HNO}_{3}$. Sorption experiments were conducted in $50 \mathrm{~mL}$ centrifuge tubes containing $20 \mathrm{~mL} \mathrm{Cd}^{2+}$ aqueous solution, $1.0 \mathrm{~g} / \mathrm{L}$ living and dead sorbents, which were agitated at a speed of $180 \mathrm{rpm}$ for $6 \mathrm{~h}$. The metal solutions used for the sorption experiments were diluted from 1000ppm (metal concentration) $\mathrm{Cd}\left(\mathrm{NO}_{3}\right)_{2}$ stock solution. All experiments were performed at ambient conditions and in triplicate. The sorbents was removed by centrifugation at $10000 \mathrm{rpm}$ for $10 \mathrm{~min}$ and the supernatant filtrated through $0.22 \mu \mathrm{m}$ filter (PVDF, Sterile) was used to measured remaining $\mathrm{Cd}^{2+}$ via ICP-MS (Perkin Elmer 600X, USA). The $\mathrm{pH}$ was measured by $\mathrm{pH}$ meter (PHS-25, 
INESA, China)(Xu et al. 2020).

\subsubsection{Biosorbent dosage effects}

To examine the effects of the biosorbent dosage, the biosorption experiments were carried out at different dosage $(0.2-3.0 \mathrm{~g} / \mathrm{L})$. The experiments were performed at optimal $\mathrm{pH} 8,30^{\circ} \mathrm{C}, 180 \mathrm{rpm}$ and $50 \mathrm{mg} / \mathrm{L} \mathrm{Cd}^{2+}$ for $6 \mathrm{~h}$. All experiments were performed at ambient conditions and in triplicate.

\subsubsection{Contact time effects and sorption kinetic characteristics}

The optimal $\mathrm{pH}(8.0)$ and biomass $(1.0 \mathrm{~g} / \mathrm{L})$ was mixed with different contact time $(0-300 \mathrm{~min})$ at $50 \mathrm{mg} / \mathrm{L} \mathrm{Cd}^{2+}$. All experiments were performed at $30^{\circ} \mathrm{C}, 180 \mathrm{rpm}$ for $6 \mathrm{~h}$ and in triplicate. To determine the rate-limiting steps by of $\mathrm{Cd}^{2+}$ biosorption by the strain LYX-1, Pseudo-first and pseudo-second order rate equation were used to fit the kinetic experimental data to study the biosorption mechanism.

Pseudo-first order kinetic model has long been widely applied(Ho 2006), The form is: $\ln \left(\mathrm{q}_{\mathrm{e}}-\mathrm{q}_{\mathrm{t}}\right)=\ln \mathrm{q}_{\mathrm{e}}-\mathrm{k}_{1} \mathrm{t}$

Where $\mathrm{q}_{\mathrm{e}}$ and $\mathrm{q}_{\mathrm{t}}$ are the amounts of the $\mathrm{Cd}^{2+}$ sorbed at equilibrium and at any time $\mathrm{t}(\mathrm{mg} / \mathrm{g}), \mathrm{k}_{1}$ is the pseudo-first order rate constant of sorption $(1 / \mathrm{min})$.

The pseudo-second order kinetic equation(Ho and McKay 1999) is shown below: $\frac{\mathrm{t}}{\mathrm{q}_{\mathrm{t}}}=\frac{1}{\mathrm{~K}_{2} \mathrm{q}_{\mathrm{e}}^{2}}+\frac{\mathrm{t}}{\mathrm{q}_{\mathrm{e}}}$

Where $\mathrm{k}_{2}$ is the pseudo-second order rate constant, $\mathrm{g} /$ (mg min), respectively, $\mathrm{q}_{\mathrm{e}}$ and $\mathrm{q}_{\mathrm{t}}(\mathrm{mg} / \mathrm{g})$ were defined elsewhere.

\subsubsection{Initial $\mathrm{Cd}^{2+}$ concentrations and sorption isotherm experiments}

The optimal $\mathrm{pH}(8.0)$ and biomass $(1.0 \mathrm{~g} / \mathrm{L})$ was mixed with different concentrations of $\mathrm{Cd}^{2+}(0-50 \mathrm{mg} / \mathrm{L})$. All experiments were performed at $30^{\circ} \mathrm{C}$ and $180 \mathrm{rpm}$ in triplicate. Langmuir and Freundlich isotherm equations were frequently used to analyze equilibrium data in related research (Masoudzadeh et al. 2011, Ozturk 2007, Zhou et al. 2018). The Cd biosorptive performance of the strain LYX-1 was simulated by using Langmuir and Freundlich isotherm equations, as follows(Freundlich 1906, Langmuir 1918) 
195 Langmuir equation: $\mathrm{q}_{\mathrm{e}}=\frac{\mathrm{q}_{\max } \mathrm{k}_{\mathrm{L}} \mathrm{C}_{\mathrm{e}}}{1+\mathrm{K}_{\mathrm{L}} \mathrm{C}_{\mathrm{e}}}$

196 Freundlich equation: $\mathrm{q}_{\mathrm{e}}=\mathrm{K}_{\mathrm{f}} \mathrm{C}_{\mathrm{e}^{\frac{1}{n}}}$

197

198

199

200

201

202

203

204

205

206

207

208

209

210

211

212

213

214

215

216

217

218

220

221

222

219 For the adsorption from aqueous solution, the adsorption potential can be defined

Where $\mathrm{q}_{\mathrm{e}}$ is the amount of $\mathrm{Cd}$ sorbed at equilibrium $(\mathrm{mg} / \mathrm{g}), \mathrm{C}_{\mathrm{e}}$ is the $\mathrm{Cd}$ equilibrium concentration $(\mathrm{mg} / \mathrm{L}), \mathrm{q}_{\max }$ is saturated sorption capacity of aqueous solution for $\mathrm{Cd}^{2+}$ and $\mathrm{K}_{\mathrm{L}}$ is a Langmuir constant related to the sorption strength. Here $\mathrm{K}_{\mathrm{F}}$ is Freundlich coefficient indicating sorption capacity, $\mathrm{n}$, a constant related to $\mathrm{Cd}$ ion concentration, characterizes adsorption intensity, respectively, $\mathrm{q}_{\mathrm{e}}$ and $\mathrm{C}_{\mathrm{e}}$ were described earlier.

Another dimensionless constant separation factor $\mathrm{R}_{\mathrm{L}}$ of Langmuir isotherm model can be expressed as following:

$\mathrm{R}_{\mathrm{L}}=\frac{1}{1+\mathrm{K}_{\mathrm{L}} \mathrm{C}_{0}}$

Where $\mathrm{C}_{0}$ is the highest $\mathrm{Cd}^{2+}$ concentration $(\mathrm{mg} / \mathrm{L}), \mathrm{K}_{\mathrm{L}}$ is a Langmuir constant, $\mathrm{R}_{\mathrm{L}}$ reflects the nature of biosorption process $\left(\mathrm{R}_{\mathrm{L}}>1\right.$ : unfavorable; $\mathrm{R}_{\mathrm{L}}=1$ : linear; $0<\mathrm{R}_{\mathrm{L}}<1$ : favorable; $\mathrm{R}_{\mathrm{L}}=0$ : irreversible).

The Dubinin-Radushkevich (D-R) was selected to study the nature of the sorption phenomena either physical or chemical sorption, govern the characteristic of not assuming a homogeneous surface or constant adsorption potential(Dubey and Gupta 2005, Zhou et al. 2018). It can be expressed as:

$\ln \mathrm{q}_{\mathrm{e}}=\ln \mathrm{q}_{\max }-\beta \varepsilon^{2}$

Where $\mathrm{q}_{\mathrm{e}}(\mathrm{mg} / \mathrm{g})$ and $\mathrm{q}_{\max }(\mathrm{mg} / \mathrm{g})$ are described above, $\beta\left(\mathrm{mol}^{2} / \mathrm{kJ}^{2}\right)$ is the parameter with respect to the mean free energy of sorption per molecule of the adsorbate, $\varepsilon(\mathrm{kJ} / \mathrm{mol})$ is the adsorption potential, and the mean free energy $\mathrm{E}(\mathrm{kJ} / \mathrm{mol})$ can be computed using following formula(Kaur et al. 2015):

$\mathrm{E}=\frac{1}{\sqrt{2 \beta}}$ as (Hu and Zhang 2019):

$\varepsilon=\mathrm{RT} \ln \left(1+1 / \mathrm{C}_{\mathrm{e}}\right)$

\subsection{PCR amplification of Cd-resistant genes}


According to the current research on the mechanism of strain resistance to $\mathrm{Cd}$, its resistance was mainly controlled by universal cadA and Czc systems(Ayangbenro et al. 2019, NIES et al. 1898, Wei et al. 2009). We could screen for the resistance genes to further explore the mechanism of reducing or eliminating heavy metal toxicity by biocontrol Paenibacillus sp., LYX-1 through PCR amplification of $\mathrm{Cd}^{2+}$-related genomes (cadA, CzcA, CzcB and CzcD). The genomic DNA of strain LYX-1. used as a template, amplified as follows: pre-denaturation at $98^{\circ} \mathrm{C}$ for $3 \mathrm{~min} ; 35$ cycles of denaturation at $98^{\circ} \mathrm{C}$ for $10 \mathrm{~s}$, annealing at $\mathrm{X}^{\circ} \mathrm{C}$ for $10 \mathrm{~s}$, extension at $72^{\circ} \mathrm{C}$ for $15 \mathrm{~s}$; followed by a final extension step at $72^{\circ} \mathrm{C}$ for $3 \mathrm{~min}$. The primer sequences selected with reference to the previous studies of the above-mentioned enzyme genes were listed in Table S1. All primers used for PCR were synthesized by Tsingke biotechnology Co., Ltd. (Beijing, China).

\subsection{Characterization to biosorption mechanisms of $\mathrm{Cd}^{2+}$ by strain LYX-1}

Samples of living and dead cells before and after $50 \mathrm{mg} / \mathrm{LCd}^{2+}$ biosorption were collected and freeze-dried for the following tests. Cells were immobilized in glutaraldehyde at $4^{\circ} \mathrm{C}$ overnight and then washed using phosphate buffer $(\mathrm{pH} 7.2)$ for 3 times. The washed biomass was finally dehydrated in alcohol, and followed by immobilization and being cut into 70-90 $\mathrm{nm}$ shin sheets for transmission electron microscopy (H-7650, Japan), scanning electron microscope coupled with energy dispersive spectroscopy (Nova Nano 450, USA) analysis. Freeze-dried biomass were prepared for Fourier Transform Infrared Spectrometry (Thermo Scientific Nicolet iN10, USA) and X-ray photo-electron spectroscopy (Thermo Scientific K-Alpha, USA) to study the fundamental properties and underlying encapsulation mechanisms of adsorbents before and after biosorption according to previous methods(Huang et al. 2020).

\subsection{Statistical analysis}

All experiments were performed in triplicates. Statistical analysis was carried out using SPSS 20.0 software. All drawing and model fittings were generated using Origin 2018 software. The phylogenetic tree was constructed by MEGA 7.0. 


\section{Results and discussion}

\subsection{The isolation and identification of biocontrol strain Paenibacillus sp. LYX-1}

Biocontrol strain Paenibacillus sp. LYX-1 with antagonistic to peach brown rot was isolated from rhizosphere soil in peach orchard in Fenghua city, Zhejiang province, China. The significant antagonism to peach brown rot could be seen in plate antagonism test from Fig. S1. The 16S rDNA sequences of LYX-1 aligned with the published sequences in NCBI database using BLAST (https://www.ncbi.nlm.nih.gov) had the highest similarity (99.62\%) with Paenibacillus sp.. The phylogenetic tree constructed also indicated that the strain had 99\% threshold with Paenibacillus sp. (Fig. 1a). Thus, it was named Paenibacillus sp.. The strain LYX-1 and its GenBank accession number was MZ234160. The strain LYX-1 has also been deposited in China General Microbiological Culture Collection Center (CGMCC accession No. 22158) as a patent strain. The strain on LB medium was round, light yellow with smooth edges(Fig. 1b). Fig. 1c proved that strain LYX-1 was Gram-positive. Biocontrol strain Paenibacillus sp. LYX-1 was also identified with higher $\mathrm{Cd}^{2+}$ resistance(Fig. 1d).
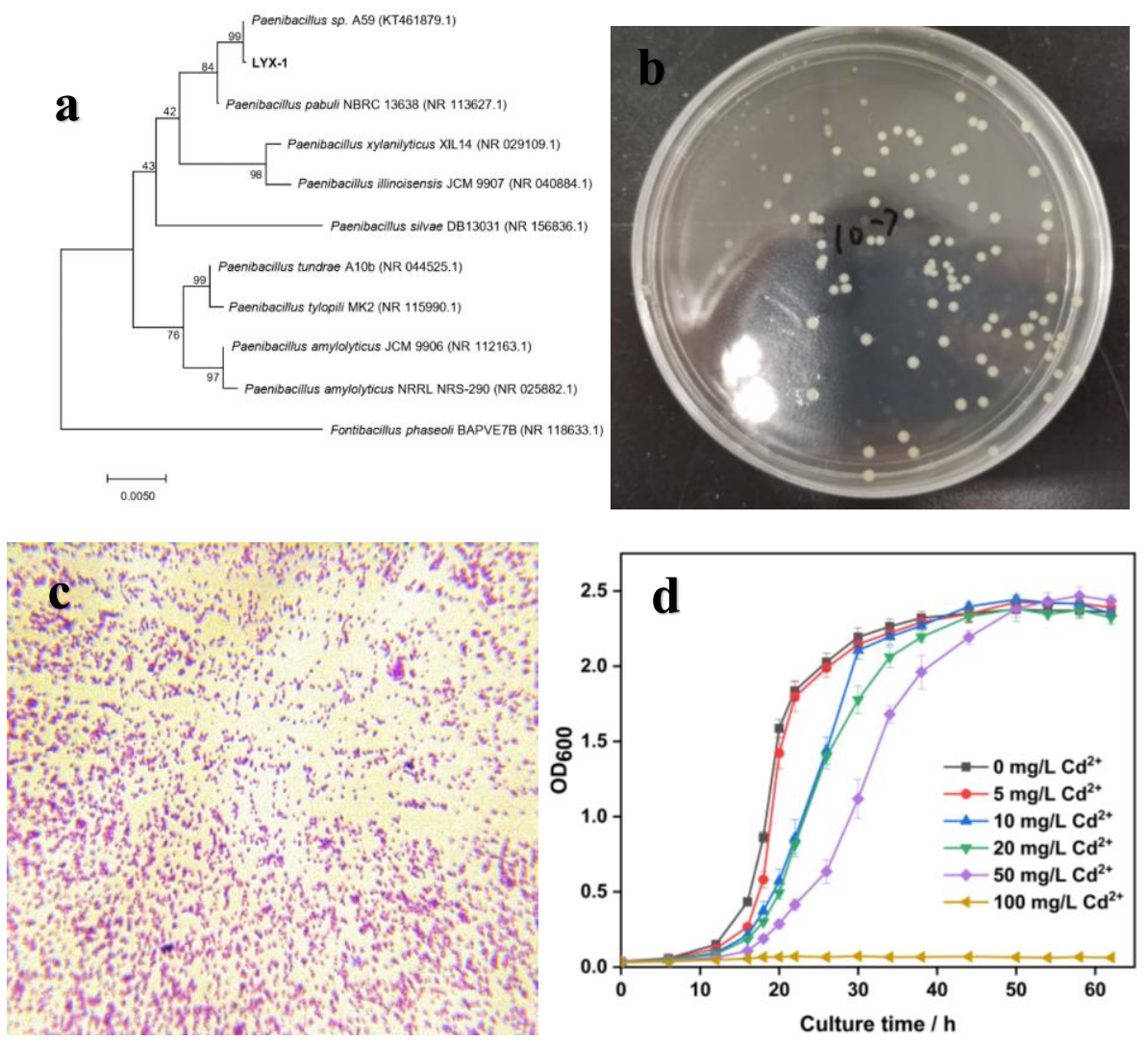

Fig. 1. (a) the neighbor-joining tree based on 16S rDNA gene sequences, showing the phylogenetic relationships 
between strain LYX-1 with other strains, (b) the colony morphology, (c) gram staining characteristics and (d) growth curves in presence of different initial $\mathrm{Cd}^{2+}$ concentrations of the Paenibacillus sp. strain LYX-1.

\subsection{Effects of $\mathrm{Cd}^{2+}$ concentrations on growth curves of Paenibacillus sp. LYX-1}

Microbial growth was influenced directly by the microbial activity under different concentrations of heavy metal(Huang et al. 2014, Sun et al. 2020, Tan et al. 2020). As shown in Fig. 1d, the growth of Paenibacillus sp. LYX-1 was barely affected and the maximum $\mathrm{OD}_{600}$ value even exceeded 2.4 under $20 \mathrm{mg} / \mathrm{L} \mathrm{Cd}^{2+}$. As the concentration increased, the logarithmic growth stage had obvious delays, which might due to stressed metabolic pathway and internal biochemical reactions(Sun et al. 2020). Increasing the $\mathrm{Cd}^{2+}$ concentrations did not significantly decreased the strain LYX-1 activity (Fig. 2), suggesting that the stain LYX-1 had a good environmental adaptability that could continue to grow in the presence of $50 \mathrm{mg} / \mathrm{L} \mathrm{Cd}^{2+}$. And, the stain could not grow when $\mathrm{Cd}^{2+}$ reached $100 \mathrm{mg} / \mathrm{L}$. In sum, the strain LYX-1 had high Cd resistance (50mg/L).

\subsection{Impact factors optimization to $\mathrm{Cd}^{2+}$ adsorption by Paenibacillus sp. LYX-1}

The $\mathrm{Cd}^{2+}$ biosorption performance of living and dead biomass was complex, and the removal efficiency of $\mathrm{Cd}^{2+}$ was closely related to $\mathrm{pH}$, initial $\mathrm{Cd}^{2+}$ concentrations, doses and contact time(Yu and Fein 2017, Zhou et al. 2014). To investigate the sorption conditions of living and dead sorbents, effects of these four independent variables were illustrated.

\subsubsection{Effects of different $p H$}

Earlier studies have shown that $\mathrm{pH}$ was an important factor affecting biosorption process, because it could directly influence the solubility of metal ions, ionization state of functional groups on the microorganism surface(Altowayti et al. 2019, Şahin and Öztürk 2005). As the initial $\mathrm{pH}$ increased, $\mathrm{Cd}^{2+}$ removal showed a rising tendency (Fig. 2a). Due to the competitive adsorption between hydrogen ions and adsorbed $\mathrm{Cd}^{2+}$ ions(Zeng et al. 2021), the equilibrium adsorption capacity of heavy metal was just 7.95 $\mathrm{mg} / \mathrm{g}$ and $6.48 \mathrm{mg} / \mathrm{g}$ for living and dead cells at the $\mathrm{pH}$ 3.0. When the $\mathrm{pH}$ reached 4.0, more charged functional groups on the cell surface, such as carboxyl, amino, and hydroxyl began to expose, which strengthened the binding of $\mathrm{Cd}^{2+}$ to the adsorption site, thereby increasing the amount of adsorption((Li et al. 2018, Özdemir et al. 2009). 
Meanwhile, as the solution $\mathrm{pH}$ increased, more $\mathrm{Cd}^{2+}$ would be fixed on to the negatively-charged cell surface due to the electrostatic adsorption. Notably, the presence of a highest point between $\mathrm{pH} 3$ and 8, the optimum $\mathrm{pH}$ value for sorption was determined at 8.0 for both living cells and dead cells, which suggested that the LYX-1 had an excellent $\mathrm{pH}$ buffering performance. It was calculated that when $\mathrm{pH}=8.0$, heavy metal ions not reached the precipitation equilibrium constant, so hydroxide precipitation not generated in the solution.

\subsubsection{Effects of initial C $\boldsymbol{d}^{2+}$ concentrations}

Fig. 2b showed the adsorption capacity of Paenibacillus sp. at different $\mathrm{Cd}^{2+}$ concentrations ranging from 0 to $50 \mathrm{mg} / \mathrm{L}$. In general, with the increase of the initial concentrations of $\mathrm{Cd}$ ions, the biosorption capacity gradually increased for both living and dead cells, which implied that an increase in the initial $\mathrm{Cd}^{2+}$ concentration generated a diving force and reduced the mass transfer resistance between $\mathrm{Cd}$ ions and sorbents(Masoudzadeh et al. 2011). Owing to the limited biosorption sites of sorbents(Xu et al. 2020), the sorption capacity reached saturation in higher concentration treatment (more than $30 \mathrm{mg} / \mathrm{L}$ ). In addition to the adsorption of living cells, there was also intracellular accumulation( $\mathrm{Li}$ et al. 2010). Herein, the adsorption capacity of living cells $(18.019 \mathrm{mg} / \mathrm{g})$ was slightly higher than dead cells $(14.847 \mathrm{mg} / \mathrm{g})$ when $\mathrm{Cd}^{2+}$ concentration was $20 \mathrm{mg} / \mathrm{L}$. Note that, the removal capacities of living and dead cells were as high as $90.39 \%$ and $75.67 \%$ under the $20 \mathrm{mg} / \mathrm{L} \mathrm{Cd}^{2+}$, respectively. Thus, the Paenibacillus sp., a promising and highly efficient biocontrol biosorbent, could be applied for heavy metal sewage treatment.

\subsubsection{Effects of adsorbent dose}

The variation of equilibrium uptake for $\mathrm{Cd}$ ions at different biosorbent dose for each living biomass and dead biomass were shown in Fig. 2c, which indicated that $\mathrm{Cd}^{2+}$ was adsorbed by the living biomass more strongly than dead biomass and two adsorbents had similar patterns for $\mathrm{Cd}$ removal. The adsorption capacity increased gradually as the biomass dose increased from 0.2 to $1.0 \mathrm{~g} / \mathrm{L}$, which could be explained that more binding sites were available and thus the biosorption capacity went up with the increase of dose(Sun et al. 2011). However, the biomass of strain LYX-1 presented 
a decline trend with an increased biosorbent dose from $1.0 \mathrm{~g} / \mathrm{L}$ to $3.0 \mathrm{~g} / \mathrm{L}$. It has been reported that biosorbent generated aggregation under high biosorbent concentrations, causing the decrease in effective contact area between cells and metal ions(Zhu et al. 2016). Therefore, the optimum living and dead cells dosage of all following experiments was selected as $1.0 \mathrm{~g} / \mathrm{L}$. Therefore, it was obvious that redundant adsorbents were not necessary for an efficient biosorption performance under specific initial concentration.

\subsubsection{Effects of contact time}

As reported by Sun(Sun et al. 2011), contact time had a significant effect on the equilibrium biosorption. $\mathrm{Cd}^{2+}$ biosorption by Paenibacillus sp. LYX-1 under different contact time $(0-300 \mathrm{~min})$ at $50 \mathrm{mg} / \mathrm{L}$ initial $\mathrm{Cd}^{2+}, \mathrm{pH} 8.0,30^{\circ} \mathrm{C}$ and $180 \mathrm{rpm}$ were studied. The effect of contact time on the amount biosorbed was presented in Fig. 2 d. For $\mathrm{Cd}^{2+}$, saturation levels of living and dead biomass were obtained after $120 \mathrm{~min}$ and 60 min, respectively, which indicated that LYX-1 had a higher adsorption efficiency. The biosorption capacity of the two adsorbents for $\mathrm{Cd}$ increased with the extension of time. It showed a fast adsorption process within 30 minutes and a slow adsorption process within 30-60 minutes for dead biosorbent. This was because the adsorption sites on the bacterial surface gradually reached saturation. After reaching 60 and 120 minutes, the adsorption curve showed a relatively gentle trend, indicating that the adsorbent and adsorbate reached adsorption equilibrium. It was also noticeable that the experimental results were consistent with previous studies on the biosorption of $\mathrm{Cd}$ ions ( $\mathrm{Li}$ et al. 2010, $\mathrm{Xu}$ et al. 2020). The shaking time was determined to be $3 \mathrm{~h}$ for the rest of the batch experiments to make sure the equilibrium was reached. 

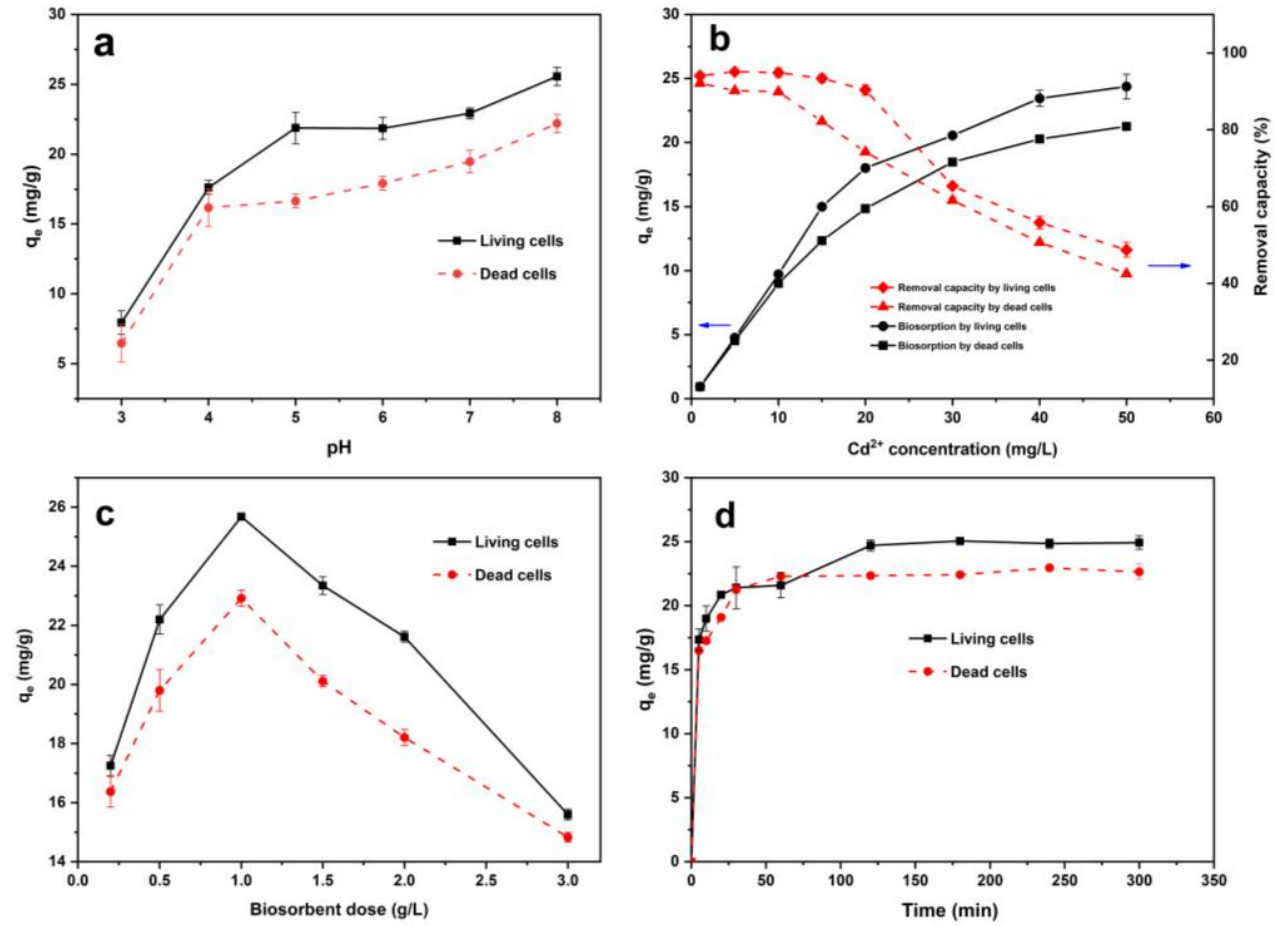

Fig. 2. Effects of environmental factor on $\mathrm{Cd}^{2+}$ biosorption by living and dead biocontrol strain LYX-1 (a) $\mathrm{pH}$ (b) initial $\mathrm{Cd}^{2+}$ concentrations (c) biosorbent dose (d) contact time.

\section{6}

357

\subsection{Adsorption kinetic characteristics}

According to formulas (1) and (2), the experimental data was fitted to obtain the kinetic fitting diagrams. As depicted in Fig. 3a and 3b, clearly, the effect of the pseudosecond-order rate equation was better than pseudo-first-order rate equation, which suggested that the influence of the mass diffusion step on the adsorption rate could be negligible and rate-limiting step was a chemical adsorption process(Ho 2006, Ho and McKay 1999). This result was consistent with numerous reports on the (Abdolali et al. 2016, Feng et al. 2011, Xu et al. 2020). The equilibrium adsorption capacity of ions calculated by the pseudo-second-order rate equation was basically consistent with the measured value (Table 1). Thus, the pseudo-second-order kinetic parameters could be used to calculate the equilibrium adsorption capacity and removal rate. 

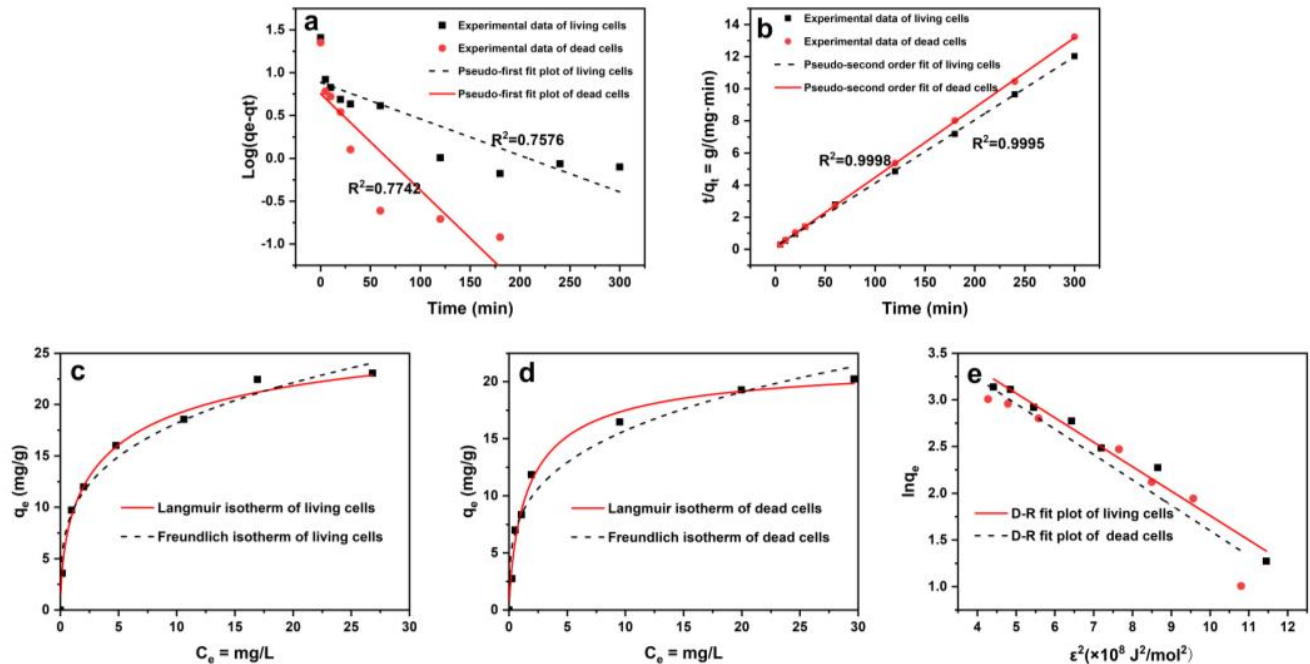

Fig. 3. The linear form of (a) Pseudo-first and (b) Pseudo-second order model for $\mathrm{Cd}^{2+}$ adsorption onto living and dead cells; biosorption isotherm images of Langmuir ( $\mathrm{q} \max : \mathrm{mg} / \mathrm{g}, \mathrm{b}$ : $\mathrm{L} / \mathrm{mg})$, Freundlich $\left(\mathrm{K}_{\mathrm{f}}, \mathrm{n}_{\mathrm{f}}(0.1<1 / \mathrm{n}<1)\right)$ for (c) $\mathrm{Cd}^{2+}$ biosorption onto living cells, (d) $\mathrm{Cd}^{2+}$ biosorption onto dead cells and Dubinin-Radushkevich (D-R) for (e)

$\mathrm{Cd}^{2+}$ biosorption onto both living and dead cells.

Table 1 Kinetic parameters obtained for the adsorption of $\mathrm{Cd}^{2+}$ using the linear method and isothermal constants, coefficient of determination $\left(\mathrm{R}^{2}\right)$ for the models fitted to equilibrium $\mathrm{Cd}^{2+}$ biosorption onto biomass Paenibacillus sp. LYX-1 strain (data calculated by equation of regression line obtained by software Origin 2018).

\begin{tabular}{|c|c|c|c|}
\hline \multirow{2}{*}{ Models } & \multirow{2}{*}{ Parameters } & \multicolumn{2}{|c|}{ biosorbents } \\
\hline & & Living biomass & dead biomass \\
\hline \multirow{4}{*}{$\begin{array}{l}\text { Pseudo-first order } \\
\text { kinetic }\end{array}$} & 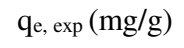 & 23.2854 & 23.2854 \\
\hline & $\mathrm{q}_{\mathrm{e}, \mathrm{cal}}(\mathrm{mg} / \mathrm{g})$ & 7.7250 & 5.7030 \\
\hline & $\mathrm{k}_{1}\left(\min ^{-1}\right)$ & $9.8338 \times 10^{-3}$ & $2.5930 \times 10^{-2}$ \\
\hline & $\mathrm{R}^{2}$ & 0.7273 & 0.7365 \\
\hline \multirow{4}{*}{$\begin{array}{l}\text { Pseudo-second order } \\
\text { kinetic }\end{array}$} & 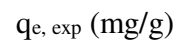 & 23.7158 & 20.5453 \\
\hline & $\mathrm{q}_{\mathrm{e}, \mathrm{cal}}(\mathrm{mg} / \mathrm{g})$ & 23.3614 & 19.9568 \\
\hline & $\mathrm{k}_{2}(\mathrm{mg} / \mathrm{g} \min )$ & $8.5471 \times 10^{-3}$ & $1.5590 \times 10^{-2}$ \\
\hline & $\mathrm{R}^{2}$ & 0.9894 & 0.9798 \\
\hline \multirow{4}{*}{ Langmuir } & $\mathrm{q}_{\max }(\mathrm{mg} / \mathrm{g})$ & 30.6790 & 24.3752 \\
\hline & $\mathrm{K}_{\mathrm{L}}(\mathrm{L} / \mathrm{g})$ & 0.4130 & 0.6244 \\
\hline & $\mathrm{R}_{\mathrm{L}}$ & 0.0461 & 0.0310 \\
\hline & $\mathrm{R}^{2}$ & 0.9704 & 0.9871 \\
\hline \multirow{3}{*}{ Freundlich } & $\mathrm{K}_{\mathrm{F}}(\mathrm{mg} / \mathrm{g})$ & 9.4936 & 8.2306 \\
\hline & $\mathrm{n}$ & 3.48831 & 4.5157 \\
\hline & $\mathrm{R}^{2}$ & 0.9915 & 0.9378 \\
\hline \multirow{3}{*}{$\begin{array}{c}\text { Dubinin- } \\
\text { Redushckevich (D-R) }\end{array}$} & $\beta\left(\mathrm{mol}^{2} / \mathrm{kJ}\right)$ & $2.6201 \times 10^{-9}$ & $2.7162 \times 10^{-9}$ \\
\hline & $\mathrm{E}(\mathrm{kJ} / \mathrm{mol})$ & 13.8313 & 13.5676 \\
\hline & $\mathrm{R}^{2}$ & 0.9757 & 0.9065 \\
\hline
\end{tabular}


surface properties and affinity of adsorbent for different heavy metal ions(Mohapatra et al. 2019). In this study, Langmuir, Freundlich and D-R isotherm models were selected to simulate favorable equilibrium uptake curve and reveal the adsorption behavior of living and dead cells Paenibacillus sp. LYX-1(Fig. 3). In case of Langmuir isotherm equation, the biosorption feature was determined by both $\mathrm{q}_{\max }$ and $\mathrm{K}_{\mathrm{L}}$ value(Ranjan et al. 2009). As shown in Fig. 3c and table 1, the regression coefficient $\mathrm{R}^{2}$ of Langmuir and Freundlich equations were 0.9704 and 0.9915 , respectively, indicating that these two models could describe the adsorption process of living biomass well. This result suggested that $\mathrm{Cd}^{2+}$ biosorption by living adsorbent was more likely to be monolayer and heterogenous surface adsorption, besides, other intracellular accumulation mechanisms might be involved in removal process of $\mathrm{Cd}^{2+}$ by living cells. In addition, the Langmuir model $\left(\mathrm{R}^{2}=0.9871\right)$ was more applicable to simulate the dead cell adsorption process than Freundlich $\left(\mathrm{R}^{2}=0.9478\right)$, indicating that the nature of biosorption by dead cells was a monolayer and non-heterogenous adsorption. As seen in table 1, the maximum adsorption capacity of living and dead cells for Cd sorption, estimated from the Langmuir $\mathrm{q}_{\max }$ parameter, was found to be $30.6790 \mathrm{mg} / \mathrm{g}$ and $24.3752 \mathrm{mg} / \mathrm{g}$. The comparison of $\mathrm{R}_{\mathrm{L}}$ for living biomass $\left(\mathrm{R}_{\mathrm{L}}=0.0461\right)$ and dead biomass $\left(\mathrm{R}_{\mathrm{L}}=0.0310\right)$ showed that living cells had a higher adsorption capacity. The high adsorption properties of Paenibacillus sp. meant that it had a strong fixation ability to $\mathrm{Cd}$ and might reduce the bioavailability of $\mathrm{Cd}^{2+}$ in the contaminated soil. Therefore, the biocontrol LYX-1 might control the migration of heavy metal pollutants into plants while exerting its biocontrol effect on pathogenic bacterium.

For D-R model, the plots of $\ln q_{\mathrm{e}}$ versus $\varepsilon^{2}$ were shown in Fig. 3e, and parameters were presented in Table 1. Additionally, the magnitude of E might give useful information about the type of adsorption process (physical or chemical)(Ishola et al. 2014, Tran et al. 2016). Physical adsorption arises from relatively weak interactions such as van der waals force, while chemical adsorption involves stronger chemical interactions (chemical bonding) with attendant transfer of electrons between the adsorbent and adsorbate(Tran et al. 2017). In essence, the value of $E$ for living and dead biomass were found to be with the range from $8 \mathrm{~kJ} / \mathrm{mol}$ to $16 \mathrm{~kJ} / \mathrm{mol}$, indicating that 
chemisorption (ion exchange complexation and precipitation) controlled the adsorption process.

\subsection{Mechanisms of $\mathrm{Cd}^{2+}$ resistance and biosorption by strain LYX-1}

\subsubsection{Amplification of Cd-resistant genes}

Paenibacillus sp. LYX-1 resistant to $\mathrm{Cd}^{2+}$ was chosen for sequence analysis of the cadA, CzcA, CzcB, CzcD, which had the potential to reduce or eliminate heavy metal $\mathrm{Cd}^{2+}$ toxicity(Wei et al. 2009). Fig. S2 showed that Paenibacillus sp. LYX-1 processed $\mathrm{Cd}^{2+}$-resistant genes $(\mathrm{CzcD})$ that could modify the protein, determine the specificity to the metal substrate, and realized the resistance to $\mathrm{Cd}$ through efflux system(Legatzki et al. 2003). The detection of $\mathrm{CzcD}$ demonstrated that Paenibacillus sp. had ability to resist $50 \mathrm{mg} / \mathrm{L} \mathrm{Cd}^{2+}$ (Fig. 2). Besides, the function of efflux $\mathrm{CzcD}$ gene further explained the insignificant difference in the maximum adsorption capacity of living $(30.6790 \mathrm{mg} / \mathrm{g})$ and dead biosorbent $(24.3752 \mathrm{mg} / \mathrm{g})$ in Table 1.

\subsubsection{TEM analysis}

In order to study the intracellular accumulation and extracellular adsorption of $\mathrm{Cd}^{2+}$ by biocontrol strain LYX-1, TEM was used to observe the changes of bacterial surface morphology in the presence of $\mathrm{Cd}^{2+}$. It could be seen from the Fig. 4a that the living control cells were full of intracellular and had uniform cytoplasm, complete cell wall structure, clear boundaries. On the one hand, when under the stress of $50 \mathrm{mg} / \mathrm{L}$ $\mathrm{Cd}^{2+}$, living biomass had a clear gap between the cell wall and cytoplasm of living biomass with high-density black particular matter appearing inside and outside the cell (Fig. 4b). This might be attributed to the contraction of the cytoplasm to increase the intracellular accumulation of $\mathrm{Cd}^{2+}$ and form a resistance mechanism(Sun et al. 2020). Additionally, this also verified the results of the previous isotherm and kinetic experiments that not only fast surface adsorption occurred in living cells, but also relatively slow intracellular accumulation (Fig. 3). After the high temperature heat treatment, the cytoplasm of dead cells severely shrank and appeared different size vacuoles (Fig. 4c), besides, Fig. 4d appeared high-density black particulate matter, indicating that the adsorption of $\mathrm{Cd}$ by dead cells was mainly concentrated on the outer edge and periplasmic space, which was consistent with Huang et al. (Huang et al. 2013). 

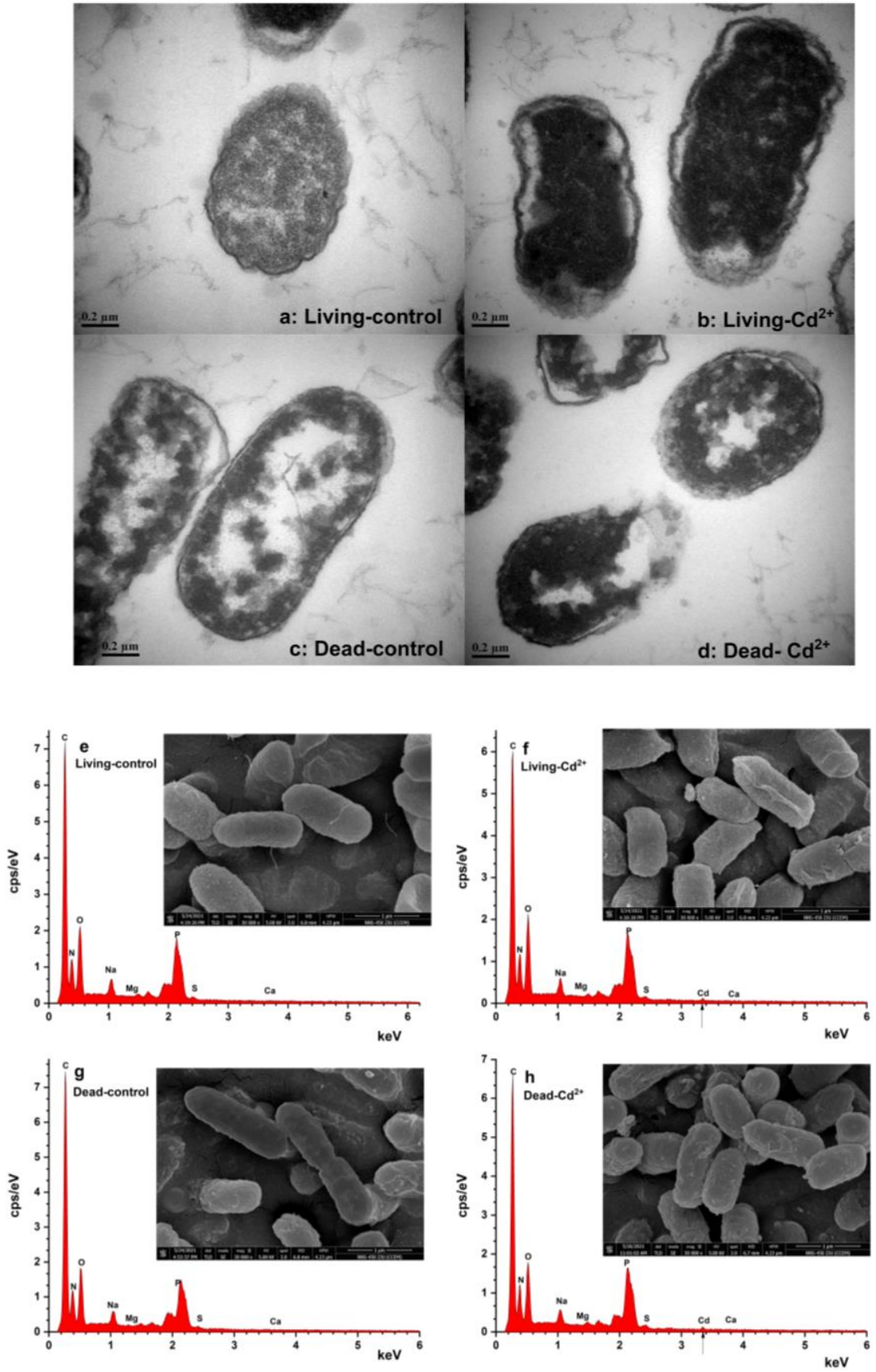

Fig. 4. Submicroscopic structures of Paenibacillus sp., LYX-1 (a) nature living cells, (b) $50 \mathrm{mg} / \mathrm{L} \mathrm{Cd}^{2+}$-loaded living cells, (c) dead cells, (d) $50 \mathrm{mg} / \mathrm{L} \mathrm{Cd}^{2+}$-loaded dead cells; scanning electron micrograph (SEM) and energy dispersive spectrometer (EDS) of the (e) living cells without $\mathrm{Cd}^{2+}$ treatment; (f) living cells treated with $50 \mathrm{mg} / \mathrm{L}$ $\mathrm{Cd}^{2+}$, (g) dead cells without $\mathrm{Cd}^{2+}$ treatment, (h) dead cells treated with $50 \mathrm{mg} / \mathrm{L} \mathrm{Cd}^{2}$.

\subsubsection{SEM-EDS analysis}

Based on the micro-characterization SEM-EDS study of biomass, Cd removal mechanism by the strain Paenibacillus sp. was further analyzed. Fig. 4(e)-(h) showed surface characteristic changes of living and dead cells morphology before and after $\mathrm{Cd}^{2+}$ removal. We found that the surface of living cells appeared smooth and short-rod 
shapes, while living cells after absorbing $\mathrm{Cd}^{2+}$ became rough and ruptured, accompanied by a large amount of flocculent sedimentation (Fig. 4e and f). Compared with living cells, dead cells seemed to be rougher, which might be caused by temperature heat treatment. After the biosorption of $\mathrm{Cd}$, precipitated materials appeared on the surface of dead cells, indicating that numerous $\mathrm{Cd}^{2+}$ ions were adsorbed on the surface of dead biomass. The EDS analysis further verified the adsorption of $\mathrm{Cd}^{2+}$ by the biosorbents. No Cd peaks were detected in pristine cells. However, the peaks of $\mathrm{Cd}^{2+}$ with all the other elements was detected in the EDS analysis of two biomass samples after Cd biosorption. Elemental variation of strain LYX-1 before and after biosorption was in Table S2. Presence of Cd on cell surface after adsorption as seen from EDS images (Fig. $\mathbf{4 g}$ and $\mathbf{4 h}$ ) proved the biosorption of $\mathrm{Cd}^{2+}$ by living and dead biosorbents of Paenibacillus sp..

\subsubsection{FTIR analysis}

In order to confirm the changes of functional groups involved in the $\mathrm{Cd}$ binding of biomass, the FTIR analysis was carried out. The FTIR spectrum of raw and $\mathrm{Cd}^{2+}-$ loaded living and dead biosorbent were presented in Fig. 5, where characteristic transmittance peaks listed in were identified according to previous reports (Chen et al. 2012, Huang et al. 2016, Sun et al. 2020).

For untreated living and dead cells, in Table S3, the peaks observed at 3429.88, 2923.73, 1647.93, 1544.78, 1236,90, 1069.97, 672.87 (living) and 3413.90, 2921.66, $1643.37,1540.02,1245.74,1054.21$ and 633.56 (dead) were assigned to associated O$\mathrm{H}, \mathrm{N}-\mathrm{H}$., $-\mathrm{CH}_{2}$, amide I (-C=O/C-N), amide II (C-N/N-H), $\mathrm{S}^{2-}, \mathrm{C}-\mathrm{N}$ and phosphate, or sulfate functional groups, respectively(Peng et al. 2020). The free $\mathrm{Cd}^{2+}$ could be fixed by the abundant oxygen-containing and amino functional groups via the formation of surface complexation, which could be described:

$$
\mathrm{Cd}^{2+}+2 \mathrm{OH}^{-} / \mathrm{LYX}-1=\mathrm{Cd}(\mathrm{OH})_{2}(\mathrm{~s}) / \mathrm{LYX}-1
$$

$$
\mathrm{Cd}^{2+}+\mathrm{PO}_{4}{ }^{3-} / \mathrm{LYX}-1=\mathrm{Cd}_{3}\left(\mathrm{PO}_{4}\right)_{2}(\mathrm{~s}) / \mathrm{LYX}-1
$$

$$
\mathrm{Cd}^{2+}+-\mathrm{CO} / \mathrm{LYX}-1 \rightarrow \mathrm{Cd}(\mathrm{CO})^{2+} / \mathrm{LYX}-1
$$

$$
\mathrm{Cd}^{2+}+-\mathrm{COOH} / \mathrm{LYX}-1 \rightarrow \mathrm{Cd}(\mathrm{COO})_{2} / \mathrm{LYX}-1+2 \mathrm{H}^{+}
$$

$$
\mathrm{Cd}^{2+}+-\mathrm{NH}_{2} / \mathrm{LYX}-1 \rightarrow \mathrm{Cd}\left(\mathrm{NH}_{2}\right)^{2+} / \mathrm{LYX}-1
$$


After $\mathrm{Cd}^{2+}$ biosorption, there was only slight shift of groups between control and $\mathrm{Cd}^{2+}$ treated groups. However, attributed to interaction between adsorbents and heavy metal, - $\mathrm{OH},-\mathrm{NH},-\mathrm{CH}_{2},-\mathrm{C}=\mathrm{O}, \mathrm{O}=\mathrm{C}-\mathrm{O}, \mathrm{C}-\mathrm{N}, \mathrm{S}^{2-}$ and phosphate functional groups were red or blue shifted when compared to nature living and dead cells, suggesting that those shifted bonds and correspond functional groups might be involved in $\mathrm{Cd}$ biosorption(Xu et al. 2020).

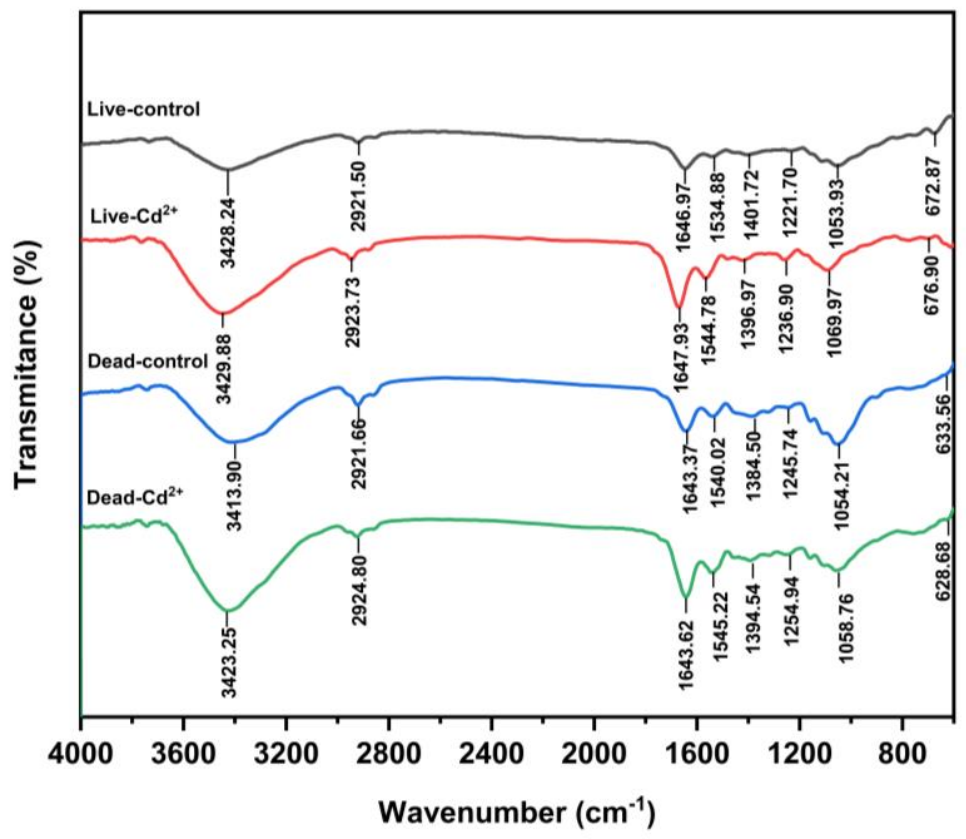

Fig. 5. FTIR spectra of the living and dead cell before and after adsorption of $\mathrm{Cd}^{2+}$.

\subsubsection{XPS analysis}

Full-range XPS spectra of Paenibacillus sp. before and after biosorption were shown on Fig. 6a, which proved $\mathrm{Cd}^{2+}$ were adsorbed onto the strain LYX-1. The peaks of $\mathrm{C}-\mathrm{O}$ at $286.31 \mathrm{eV}$ and $286.39 \mathrm{eV}$ (BE) of living and dead cells, respectively, were slightly reduced (Fig. 6b), which indicated that surface reducing groups such as $\mathrm{C}-\mathrm{OH}$ could form precipitation with $\mathrm{Cd}^{2+}$ or provide protons to promote the formation of $\mathrm{CO}$ $\mathrm{Me}\left(\mathrm{CO}-\mathrm{Cd}^{2+}\right)$ (Ho et al. 2017). By comparing the $\mathrm{O} 1 \mathrm{~s}$ spectra of the control and experimental groups, the peaks of $\mathrm{O} 1 \mathrm{~s}$ at $532.60 \mathrm{eV}$ and $532.62 \mathrm{eV}$ of living and dead cells were also considered as $\mathrm{C}-\mathrm{O}-\mathrm{Cd}^{2+}($ Fig. 6c). Peaks of $\mathrm{Cd}$ detected after the adsorption could be divided into peaks at $405.39 \mathrm{ev}$ and $411.98 \mathrm{ev}$, corresponding to $\mathrm{Cd}$ $3 \mathrm{~d}_{5 / 2}$ and $\mathrm{Cd} 3 \mathrm{~d}_{3 / 2}$ (Fig. 6d), respectively. There peaks $(404.85 \mathrm{eV}, 405.30 \mathrm{eV}, 405.78 \mathrm{eV}$ for living cells, $404.80 \mathrm{eV}, 405.30 \mathrm{eV}$ and $405.78 \mathrm{eV}$ for dead cells ) could be possibly 
ascribed to $\mathrm{Cd}(\mathrm{OH})_{2}, \mathrm{CdCO}_{3}$, and $\mathrm{CdS}$. Fig. 6e and Fig. 6f also demonstrated the generation of $\mathrm{CdS}$ precipitation. XPS results also identified that Chemisorption controlled the biosorption process of $\mathrm{Cd}^{2+}$ by LYX-1 (Fig.3e).
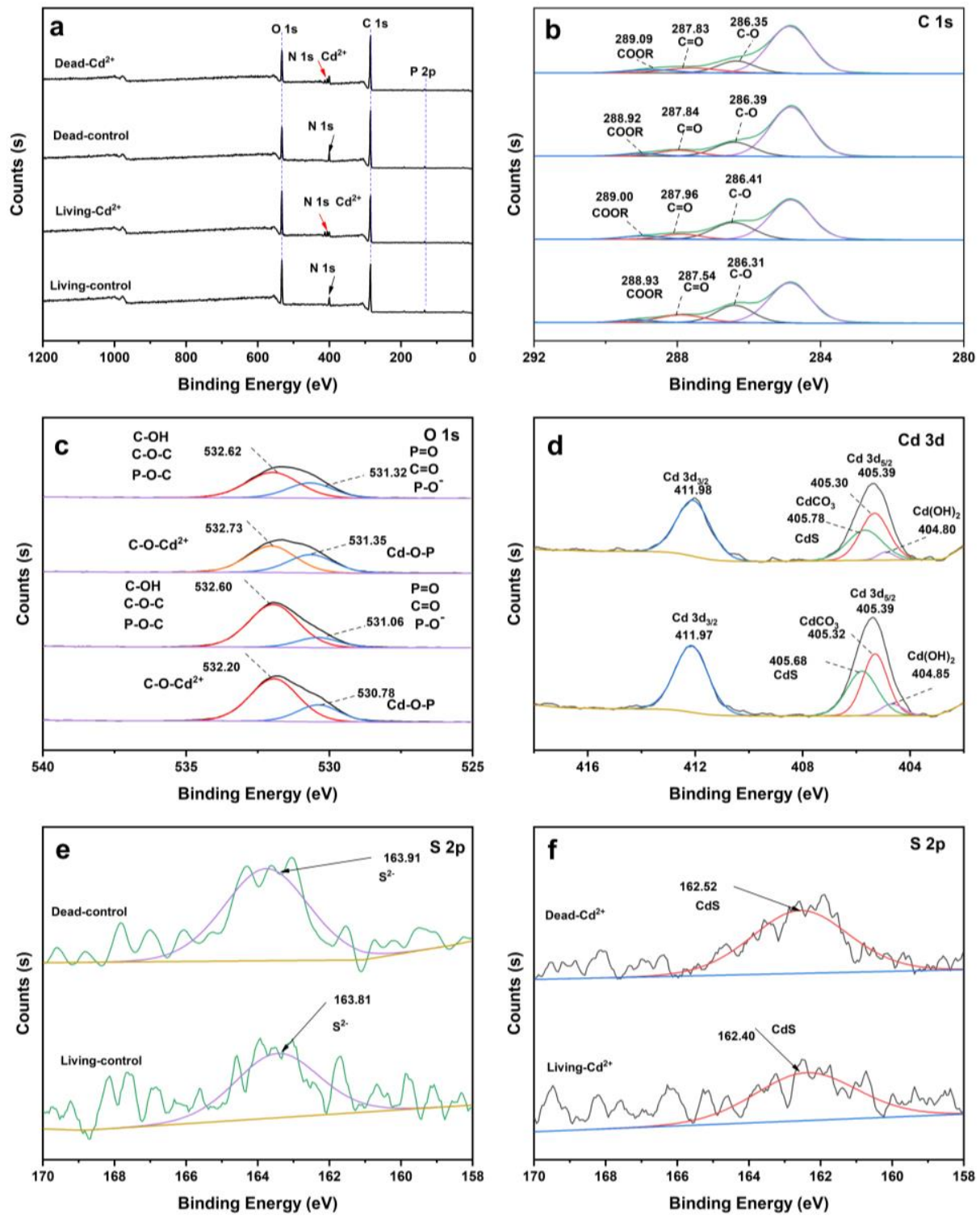

Fig. 6. XPS spectra of Paenibacillus sp. LYX-1 living and dead cells before and after adsorption of $\mathrm{Cd}^{2+}$. (a) Wide scan, (b) C 1s spectra, (c) O 1s spectra, (d) Cd 3d spectra, (e) S 2p spectra before biosorption, (f) S 2p spectra after biosorption.

\section{Conclusions}

This study successfully isolated and identified a novel biocontrol bacterium with

509 high-Cd resistance from soil contaminated by HMs, named Paenibacillus sp. LYX-1.

510 PCR amplification showed that LYX-1 had the CzcD gene responsible for $\mathrm{Cd}$

511 detoxification by removing $\mathrm{Cd}^{2+}$ from the cytoplasm or periplasmic to extracellular 
medium. $\mathrm{pH}$, initial $\mathrm{Cd}^{2+}$ concentration, adsorbent dose and contact time had significant effects on the Cd capacity of living and dead biomass in batch adsorption test. Pseudosecond order kinetic model was more suitable to two biosorbents. The fitting of Langmuir and Freundlich isotherm showed that there was a monolayer and heterogenous surface process for living cells, while monolayer and non-heterogenous process for dead cells. The E value of two biomasses ranged from $8 \mathrm{~kJ} / \mathrm{mol}$ to $16 \mathrm{~kJ} / \mathrm{mol}$, revealing that chemisorption controlled the adsorption of $\mathrm{Cd}^{2+}$ by Paenibacillus $\mathrm{sp}$. The maximum capacity obtained were $30.6790 \mathrm{mg} / \mathrm{g}$ (living biomass) and $24.3752 \mathrm{mg} / \mathrm{g}$ (dead biomass), respectively. TEM, SEM-EDS, FTIR and XPS characterization indicated that extracellular precipitation, ion exchange, and intracellular accumulation might be the main mechanisms for the adsorption of $\mathrm{Cd}^{2+}$ by living cells, while there was no intracellular accumulation for dead cells. $-\mathrm{OH},-\mathrm{NH},-\mathrm{C}=\mathrm{O}, \mathrm{O}=\mathrm{C}-\mathrm{O}, \mathrm{C}-\mathrm{N}, \mathrm{S}^{2-}$ and phosphate functional groups participated in the adsorption process of $\mathrm{Cd}$. Therefore, this novel biocontrol Paenibacillus sp. can be applied as a promising adsorbent to be used in the simultaneous control of plant rhizosphere diseases and $\mathrm{Cd}$ pollution in soil.

\section{Compliance with ethics guidelines}

This article dose not contain any studies with human or animal subjects performed by either of authors.

\section{Consent for publication}

All authors have read the submitted version of the manuscript and agree to submit the work to Environmental Science and Pollution Research, and we all agree that the transfer of copyright from the author to Environmental Science and Pollution Research.

\section{Availability of data and materials}

All data generated or analysed during this study are included in this published article and its supplementary information files.

\section{Contributors}


540 Fan performed the experiment. Yixin Luo, Min Liao and Xiaomei Xie analysed the data

541 and wrote the manuscript. All authors contributed to the discussion of the manuscript.

542

\section{Declaration of competing interest}

The authors declare that they have no known competing financial interests or personal relationships that could have appeared to influence the work reported in this paper

\section{Acknowledgements}

This work was financially funded by the Nation Key Research and Development project of China and the National Natural Science Fund of China (grant number 2018YFC1800403, 41571226).

\section{References}

Abdolali, A., Ngo, H.H., Guo, W., Lu, S., Chen, S.S., Nguyen, N.C., Zhang, X., Wang, J. and Wu, Y. (2016) A breakthrough biosorbent in removing heavy metals: Equilibrium, kinetic, thermodynamic and mechanism analyses in a lab-scale study. Sci. Total Environ. 542(Pt A), 603-611.

Abou-Shanab, R.A., van Berkum, P. and Angle, J.S. (2007) Heavy metal resistance and genotypic analysis of metal resistance genes in gram-positive and gram-negative bacteria present in $\mathrm{Ni}$-rich serpentine soil and in the rhizosphere of Alyssum murale. Chemosphere 68(2), 360-367. Ali, M.A., Lou, Y., Hafeez, R., Li, X., Hossain, A., Xie, T., Lin, L., Li, B., Yin, Y., Yan, J. and An, Q. (2020) Functional Analysis and Genome Mining Reveal High Potential of Biocontrol and Plant Growth Promotion in Nodule-Inhabiting Bacteria Within Paenibacillus polymyxa Complex. Front. Microbiol. 11, 618601.

Altowayti, W.A.H., Algaifi, H.A., Bakar, S.A. and Shahir, S. (2019) The adsorptive removal of As (III) using biomass of arsenic resistant Bacillus thuringiensis strain WS3: Characteristics and modelling studies. Ecotoxicol. Environ. Saf. 172, 176-185.

Araujo, R., Dunlap, C. and Franco, C.M.M. (2020) Analogous wheat root rhizosphere microbial successions in field and greenhouse trials in the presence of biocontrol agents Paenibacillus peoriae SP9 and Streptomyces fulvissimus FU14. Mol. Plant Pathol. 21(5), 622-635.

Ayangbenro, A.S., Babalola, O.O. and Aremu, O.S. (2019) Bioflocculant production and heavy metal sorption by metal resistant bacterial isolates from gold mining soil. Chemosphere 231, 113-120. 
Chen, Z., Huang, Z., Cheng, Y., Pan, D., Pan, X., Yu, M., Pan, Z., Lin, Z., Guan, X. and Wu, Z. (2012) Cr(VI) uptake mechanism of Bacillus cereus. Chemosphere 87(3), 211-216.

Dell'Amico, E., Mazzocchi, M., Cavalca, L., Allievi, L. and Andreoni, V. (2008) Assessment of bacterial community structure in a long-term copper-polluted ex-vineyard soil. Microbiol. Res. 163(6), 671-683. Dubey, S.S. and Gupta, R.K. (2005) Removal behavior of Babool bark (Acacia nilotica) for submicro concentrations of $\mathrm{Hg}^{2+}$ from aqueous solutions: a radiotracer study. Sep. Purif. Technol. 41(1), 21-28. Feng, N., Guo, X., Liang, S., Zhu, Y. and Liu, J. (2011) Biosorption of heavy metals from aqueous solutions by chemically modified orange peel. J. Hazard. Mater. 185(1), 49-54.

Freundlich, H.M.F. (1906) Over the adsorption in solution. J. Chem. Phys. 57, 385-470. Galkiewicz, J.P. and Kellogg, C.A. (2008) Cross-Kingdom Amplification Using Bacteria-Specific Primers: Complications for Studies of Coral Microbial Ecology. Appl. Environ. Microbiol. 74(24), 7828-7831.

Han, H., Wang, Q., He, L.Y. and Sheng, X.F. (2018) Increased biomass and reduced rapeseed Cd accumulation of oilseed rape in the presence of $\mathrm{Cd}$-immobilizing and polyamine-producing bacteria. J. Hazard. Mater. 353, 280-289.

Hao, Z., Van Tuinen, D., Wipf, D., Fayolle, L., Chataignier, O., Li, X., Chen, B., Gianinazzi, S., GianinazziPearson, V. and Adrian, M. (2017) Biocontrol of grapevine aerial and root pathogens by Paenibacillus sp. strain B2 and paenimyxin in vitro and in planta. Biol. Control 109, 42-50.

Ho, S.H., Chen, Y.D., Yang, Z.K., Nagarajan, D., Chang, J.S. and Ren, N.Q. (2017) High-efficiency removal of lead from wastewater by biochar derived from anaerobic digestion sludge. Bioresour. Technol. 246, 142-149.

Ho, Y.S. (2006) Review of second-order models for adsorption systems. J. Hazard. Mater. 136(3), 681689.

Ho, Y.S. and McKay, G. (1999) Pseudo-second order model for sorption processes. Process Biochem 34(5), 451-465.

Hu, Q. and Zhang, Z. (2019) Application of Dubinin-Radushkevich isotherm model at the solid/solution interface: A theoretical analysis. J. Mol. Liq. 277, 646-648.

Huang, D., Xue, W., Zeng, G., Wan, J., Chen, G., Huang, C., Zhang, C., Cheng, M. and Xu, P. (2016) Immobilization of $\mathrm{Cd}$ in river sediments by sodium alginate modified nanoscale zero-valent iron: Impact on enzyme activities and microbial community diversity. Water Res. 106, 15-25.

Huang, F., Dang, Z., Guo, C.L., Lu, G.N., Gu, R.R., Liu, H.J. and Zhang, H. (2013) Biosorption of Cd(II) by live and dead cells of Bacillus cereus RC-1 isolated from cadmium-contaminated soil. Colloids Surf. B 107, 11-18.

Huang, F., Guo, C.L., Lu, G.N., Yi, X.Y., Zhu, L.D. and Dang, Z. (2014) Bioaccumulation characterization of cadmium by growing Bacillus cereus RC-1 and its mechanism. Chemosphere 109, 134-142.

Huang, H., Jia, Q., Jing, W., Dahms, H.U. and Wang, L. (2020) Screening strains for microbial biosorption technology of cadmium. Chemosphere 251, 126428.

Ishola, M.M., Isroi and Taherzadeh, M.J. (2014) Effect of fungal and phosphoric acid pretreatment on ethanol production from oil palm empty fruit bunches (OPEFB). Bioresour. Technol. 165, 9-12.

Jin, Z., Deng, S., Wen, Y., Jin, Y., Pan, L., Zhang, Y., Black, T., Jones, K.C., Zhang, H. and Zhang, D. (2019) Application of Simplicillium chinense for $\mathrm{Cd}$ and $\mathrm{Pb}$ biosorption and enhancing heavy metal phytoremediation of soils. Sci. Total Environ. 697, 134148.

Jin, Z., Xie, L., Zhang, T., Liu, L., Black, T., Jones, K.C., Zhang, H., Wang, X., Jin, N. and Zhang, D. (2020) Interrogating cadmium and lead biosorption mechanisms by Simplicillium chinense via infrared spectroscopy. Environ. Pollut. 263(Pt A), 114419. 
Kaur, S., Rani, S., Mahajan, R.K., Asif, M. and Gupta, V.K. (2015) Synthesis and adsorption properties of mesoporous material for the removal of dye safranin: Kinetics, equilibrium, and thermodynamics. J Ind Eng Chem 22, 19-27.

Langmuir, I. (1918) The adsorption of gases on plane surfaces of glass, mica and platinum. J. Am. Chem. Soc.40, 1361-1403.

Legatzki, A., Grass, G., Anton, A., Rensing, C. and Nies, D.H. (2003) Interplay of the Czc system and two P-type ATPases in conferring metal resistance to Ralstonia metallidurans. J. Bacteriol. 185(15), 43544361.

Li, F., Wang, W., Li, C., Zhu, R., Ge, F., Zheng, Y. and Tang, Y. (2018) Self-mediated pH changes in culture medium affecting biosorption and biomineralization of $\mathrm{Cd}^{2+}$ by Bacillus cereus $\mathrm{Cd} 01$. J. Hazard. Mater. 358, 178-186.

Li, H., Lin, Y., Guan, W., Chang, J., Xu, L., Guo, J. and Wei, G. (2010) Biosorption of Zn(II) by live and dead cells of Streptomyces ciscaucasicus strain CCNWHX 72-14. J. Hazard. Mater. 179(1-3), 151-159.

Masoudzadeh, N., Zakeri, F., Lotfabad, T., Sharafi, H., Masoomi, F., Zahiri, H.S., Ahmadian, G. and Noghabi, K.A. (2011) Biosorption of cadmium by Brevundimonas sp. ZF12 strain, a novel biosorbent isolated from hot-spring waters in high background radiation areas. J. Hazard. Mater. 197, 190-198.

Mohapatra, R.K., Parhi, P.K., Pandey, S., Bindhani, B.K., Thatoi, H. and Panda, C.R. (2019) Active and passive biosorption of $\mathrm{Pb}(\mathrm{II})$ using live and dead biomass of marine bacterium Bacillus xiamenensis PbRPSD202: Kinetics and isotherm studies. J. Environ. Manage. 247, 121-134.

Nies, A., Nies, D.H. and Silver, S. (1990) Nucleotide sequence and expression of a plasmid-encoded chromate resistance determinant from Alcaligenes eutrophus. J. Biol. Chem. 265(10), 5648-5653.

NIES, D.H., NIES, A., CHU, L. and SILVER, A.S. (1898) Expression and nucleotide sequence of a plasmiddetermined divalent cation efflux system from Alcaligenes eutrophus. Proc. Natl. Acad. Sci. U.S.A. 86, 7351-7355.

Olaniran, A.O., Balgobind, A. and Pillay, B. (2013) Bioavailability of heavy metals in soil: impact on microbial biodegradation of organic compounds and possible improvement strategies. Int. J. Mol. Sci. 14(5), 10197-10228.

Özdemir, S., Kilinc, E., Poli, A., Nicolaus, B. and Güven, K. (2009) Biosorption of Cd, Cu, Ni, Mn and Zn from aqueous solutions by thermophilic bacteria, Geobacillus toebii sub.sp. decanicus and Geobacillus thermoleovorans sub.sp. stromboliensis: Equilibrium, kinetic and thermodynamic studies. Chem. Eng.J. 152(1), 195-206.

Ozturk, A. (2007) Removal of nickel from aqueous solution by the bacterium Bacillus thuringiensis. J. Hazard. Mater. 147(1-2), 518-523.

Peng, D., Qiao, S., Luo, Y., Ma, H., Zhang, L., Hou, S., Wu, B. and Xu, H. (2020) Performance of microbial induced carbonate precipitation for immobilizing $\mathrm{Cd}$ in water and soil. J. Hazard. Mater. 400, 123116. Ranjan, D., Talat, M. and Hasan, S.H. (2009) Biosorption of arsenic from aqueous solution using agricultural residue 'rice polish'. J. Hazard. Mater. 166(2-3), 1050-1059.

Şahin, Y. and Öztürk, A. (2005) Biosorption of chromium(VI) ions from aqueous solution by the bacterium Bacillus thuringiensis. Process Biochem 40(5), 1895-1901.

Shi, Z., Qi, X., Zeng, X.A., Lu, Y., Zhou, J., Cui, K. and Zhang, L. (2021) A newly isolated bacterium Comamonas sp. XL8 alleviates the toxicity of cadmium exposure in rice seedlings by accumulating cadmium. J. Hazard. Mater. 403, 123824.

Sun, F., Sun, W.-L., Sun, H.-M. and Ni, J.-R. (2011) Biosorption behavior and mechanism of beryllium from aqueous solution by aerobic granule. Chem. Eng.J. 172, 783-791. 
Sun, R., Wang, L., Huang, R., Huang, F., Gan, D., Wang, J., Guan, R., Han, W., Qu, J., Yan, L. and Zhang, Y. (2020) Cadmium resistance mechanisms of a functional strain Enterobacter sp. DNB-S2, isolated from black soil in Northeast China. Environ. Pollut. 263.

Tan, H., Wang, C., Zeng, G., Luo, Y., Li, H. and Xu, H. (2020) Bioreduction and biosorption of Cr(VI) by a novel Bacillus sp. CRB-B1 strain. J. Hazard. Mater. 386, 121628.

Tran, H.N., You, S.-J. and Chao, H.-P. (2016) Thermodynamic parameters of cadmium adsorption onto orange peel calculated from various methods: A comparison study. J. Environ. Chem. Eng. 4(3), 26712682.

Tran, H.N., You, S.J., Hosseini-Bandegharaei, A. and Chao, H.P. (2017) Mistakes and inconsistencies regarding adsorption of contaminants from aqueous solutions: A critical review. Water Res. 120, 88-116. Wei, G., Fan, L., Zhu, W., Fu, Y., Yu, J. and Tang, M. (2009) Isolation and characterization of the heavy metal resistant bacteria CCNWRS33-2 isolated from root nodule of Lespedeza cuneata in gold mine tailings in China. J. Hazard. Mater. 162(1), 50-56.

Xu, S., Xing, Y., Liu, S., Hao, X., Chen, W. and Huang, Q. (2020) Characterization of $\mathrm{Cd}^{2+}$ biosorption by Pseudomonas sp. strain 375, a novel biosorbent isolated from soil polluted with heavy metals in Southern China. Chemosphere 240, 124893.

Yu, Q. and Fein, J.B. (2017) Enhanced Removal of Dissolved Hg(II), Cd(II), and Au(III) from Water by Bacillus subtilis Bacterial Biomass Containing an Elevated Concentration of Sulfhydryl Sites. Environ. Sci. Technol. 51(24), 14360-14367.

Zeng, G., Qiao, S., Wang, X., Sheng, M., Wei, M., Chen, Q., Xu, H. and Xu, F. (2021) Immobilization of cadmium by Burkholderia sp. QY14 through modified microbially induced phosphate precipitation. J. Hazard. Mater. 412, 125156.

Zhou, W., Liu, D., Zhang, H.o., Kong, W. and Zhang, Y. (2014) Bioremoval and recovery of Cd(II) by Pseudoalteromonas sp. SCSE709-6: Comparative study on growing and grown cells. Bioresour. Technol. $165,145-151$.

Zhou, X., Li, H., Liu, D., Hao, J., Liu, H. and Lu, X. (2018) Effects of toxin from Bacillus thuringiensis (Bt) on sorption of $\mathrm{Pb}$ (II) in red and black soils: equilibrium and kinetics aspects. J. Hazard. Mater. 360, 172181.

Zhu, W., Xu, X., Xia, L., Huang, Q. and Chen, W. (2016) Comparative Analysis of Mechanisms of Cd ${ }^{2+}$ and $\mathrm{Ni}^{2+}$ Biosorption by Living and Nonliving Mucoromycote sp. XLC. Geomicrobiol. J. 33(3-4), 274-282. 


\section{Supplementary Files}

This is a list of supplementary files associated with this preprint. Click to download.

- SupplementalMaterial10.2.docx 